\title{
The Sinoman Hadrah Cultural Communication of Banjar Tribe as Islamic Media and Art for Welcoming Sei Teras Honorary Guest
}

\author{
Muzahid Akbar Hayat* Rico \\ Islamic University of Kalimantan, Indonesia
}

\begin{abstract}
Indonesia is rich in ethnicity and culture. The diversity of cultures in Indonesia is a manifestation of Indonesia's heritage as Bhinneka Tunggal Ika country. Indonesia's diversity of art and culture are explored, develop, and preserve hereditary. The effort has quite an important advantage for the existing art and culture. Art characteristics show where it is from and it is related to communication studies. Traditional cultural art messages not only show as a drama but also as a communication medium that is embedded in cultural values of tribe and region. Sinoman hadrah art grows and thrives at Banjar tribe as medium and art inanimate heritage in important event especially for welcoming honorary guest also as an Islamic medium for inviting young generation to live in harmony and dignity. This research used a qualitative-descriptive approach. The research data were analyzed by used Miles and Huberman's descriptive analysis model based on perception theory. The results show culture communication in sinoman hadrah performance of Banjar tribe being Islamic art and medium for welcoming honorary guests of Sei Teras village at Kapuas Kuala as well as culture hereditary containing moral, harmony, Islamic relationship and will be preserved by future generations as part of tribe honor.
\end{abstract}

Keywords: Culture Communication, Tribe, Sinoman Hadrah, Medium, Art, Heritage

DOI: $10.7176 /$ RHSS/11-18-05

Publication date:September $30^{\text {th }} 2021$

\section{Introduction}

Every country has different unique external events to another (Kapferer \& Michaut-Denizeau, 2020). It became a country's identity and attractiveness included Indonesia. Indonesia has tribe diversity and rich culture. Tribe diversity and rich culture are Indonesian heritage as Bhinneka Tunggal Ika signify to different but one. Based on it, Indonesian people can choose a culture or tradition from the community environment. Art is a universal element reflected as human civilization support. Almost every region has different unique art and cultural heritage from another. So, a frequent local art and culture performance from each region would encourage patriotism spirit to be more creative in increasing Indonesian culture existence.

Art and human are inseparable. Art is a manifestation of human feeling and human culture origin. Art can be motivation and education. Pleasure education as motivation such as social participation reward (Ito, 2010). Since the illiteracy era, art became part of human life. Art as an element of culture is a human creative expression that has majesty and beauty. Traditional performance art was preserved by the community to develop.

Indonesia has explored, develop, and preserve hereditary art and diversity. The effort has quite an important advantage for the existence of cultural art. In art, there's any characteristic symbol of community. The harmony between developing and advance national culture effort could be accused art position because national culture is a large unit consisting of various cultures, for example, traditional arts. The symbols are simple or complex implied communication. It means an idea taken together to become an important part of the culture (Klinenberg, 2013).

Community characteristic in an art showing the origin. Art is closely related to communication studies because cultural life should know cultural communication concepts. Art performance is communicative so the community would get the messages and purpose easier. Traditional performances contain messages not only a performance with drama elements but also communication medium attached cultural values of a tribe and region, as well as activity and motivation for the community. Duffett (2013) argues that cultural activities represent values inherent in society, based on people's motivation to be involved in various activities individually or as a community.

Sei Teras Village, Kapuas Kuala District located in Kapuas Regency area of Central Kalimantan Province. Sei Teras is close by South Kalimantan Province. But $87 \%$ of the population is Banjar tribe community. So, Banjar tribe inherent to characteristic cultural as daily language and social interaction such as wedding and welcoming honorary guest by sinoman hadrah cultural art performance.

For Banjar tribe, sinoman hadrah was growing and develop. Sinoman hadrah originated from the words sinoman and hadrah. Sinoman means an association of people with the same aims and objectives, while hadrah originated from the word hadrun (Arabic) means present. So hadrah means an activity to welcome the presence of a person/group who is respected or honored. Several kinds of tools are used in the performing arts of sinoman hadrah, they are tambourines, baboons, ketipung, tambourines, flags and decorated large umbrellas. These tools will become symbols and communication media to implementation of sinoman hadrah culture. Every society is 
full of symbols to communicate an idea (Klinenberg, 2013). Sinoman hadrah danced by group, expects all actors in this art to have a good and satisfying experience because practice refers to satisfy experiences related to community goals (Ito 2010). Along with the rapid development of media, sinoman hadrah art is unique and a symbol of honorary Banjar tribe culture.

This art contains various kinds of messages like Islamic faith, morals, and harmony are expected to be used as an information media to respect one to another and extensive knowledge. Values refer to desirable and worthy, they exist at several levels, at a collective level, cultural values are widely shared, an abstract idea about good, right, and desirable (Williams, 1970).

\section{Literature}

\subsection{Cultural Communication in the Arts}

The meaning of communication is understanding was expanded to the culture because it related between the elements of culture and communication to build relation and life together. Communication is a sound form that is used through daily language, so to understand and communicate right must be studied in the culture itself. Cultural communication role is crucial to the survival rich country in art because in it a person will understand where and how their arts could become communication media to survive local wisdom and their living environment referred to habitats. Habitat in the way to grow and socialize with others has become our routine (Bourdieu, 1992).

Culture is the way humans talk and dress, the food that humans eat and the way humans prepare and consume it, the way humans share time, space, and values that are socialized to society, all the details that shape and practice daily life, practice patterns of self-development and self-improvement (Spano, 2016). This perspective about the culture implies that no culture is internally superior to other cultures and cultural wealth has nothing to do with economic status, culture as everyday life is a democratic idea.

Culture is an interesting concept. Formally, culture is defined as the order of knowledge, experience, beliefs, time, roles, universe concepts, and theory objects that are acquired by preserved as an individual or group efforts. Culture is a tool or set of ideas and learned skills by our living environment culture and valid to practical situations in our own lives (Swidler 1986). Culture appeared in language patterns, form activities, and behavior to function as adaptation behavior models and communication styles to enable people who live in the geographic environment at a level technical development certain and at time. Communication culture and culture can't be separated therefore culture not only determines who talks to whom, about what, and how communication takes place but also determines the person who became the message, the meaning of his message, and his conditions to sending, paying attention and interpret messages. The reality of behavior depends on the human environment and where he was raised. The thing that indicates to culture is the basis of communication, when cultures are diverse, the practice of communication models is also diverse and becomes a nation love idea. Two important cultural things are: a love idea as voluntary choice and committed to others (Swidler 1986).

Cultural communication is also interpreted as the process of social daily life, the messages and information appeared through similarities getting significance and values that exist in a community. It is communication that happened in the same culture. National values, occupations, industrial and individuals all influence the development of cultural values in the community (Schwartz, 2014).

\subsection{Communication function in the culture}

Culture as a meaning system or symbols and culture as values, beliefs, and practices describe communication form, it is the meaningful information shared to society, language refers to a comprehensive system of words or symbols that represent concepts, and it doesn't need to be spoken, as hundred people suggest to various sign languages to use around the world (Klinenberg, 2013).

Based on (Gorden, 1978) format, there are four communication functions: First, social communication, communication functions as social communication at least implies that communication is important to build selfconcept, self-actualization, for survival, happiness, avoid pressure and tension, such as entertainment communication, and build a relationship with other.

Second, expressive communication, closely related to social communication is one or group expressive communication. Expressive communication does not purpose to influence others, but it can be done as a thing to convey feelings (emotions). These feelings are mainly communicated through nonverbal messages. Love, care, longing, sadness, happiness, anger, etc. can be conveyed through words, but mainly through nonverbal behavior.

Third, ritual communication, closely related to expressive communication is ritual communication, usually done collectively. A community frequently do different ceremonies year around that called rites of passage, from birth ceremonies, circumcision, birthdays, engagements, siraman, weddings (ijab qabul, sungkeman or paying respects to parents), in these events people show symbolic behaviors. Those who participate in ritual communication emphasize their commitment to their family traditions, community, ethnicity, nation, state, ideology, or religion. 
Fourth, instrumental communication has several purposes, to inform, teach, encourage, change attitudes and beliefs, and change behavior or act moving, also entertain. The summarized, persuade are the purposes (persuasive). The communication functions are informed or explain a persuasive, which means the speaker wants his listeners to believe that the facts or information are accurate and worth.

Culture has an integrative function to provide community-based and orientation, so it creates enthusiasm, safety, belonging, and taste as a community. Culture also creates peace of community life customs, mysticism and decency, language and literature from human imagination, and society comfortable feel that new person or an outsider does not share the knowledge, taste, spirit, expression, and appreciation to the community. A common culture to all humans, as we know, all human society throughout history has used language to communicate with each other. Some linguists argue that language is mind-basic - if you don't have a word for something, you really can't think. The viewpoint implication is group's language is directly responsible for many cultural symbols and practices (Klinenberg, 2013).

Sinoman hadrah art has various education and moral value be given one to another. The educational and moral cover religious norms, manners and ethics, beauty or aesthetics, self-appearance, self-placement in society, living in personal and community interests, respecting others, behaving well, and so on. Communication occurs reciprocally between hadrah sinoman actors and audiences through various kinds of poetry, equipment, and symbols used. The symbol is enabling people to share and interpret culture simultaneously (Burgess and Green 2009).

\subsection{Culture as National Identity}

Country culture is an infinite legacy because a country or nation will be easily recognized by culture region as a symbol and norm. Symbols, rituals, norms, and society general practices development reflect and express the values of cultural organization maker. (Sagiv \& Schwartz, 2000; 2007; Trice \& Beyer, 1993). Culture influences human thinking, speech, and behavior. Society environment, which individuals are born and live, make his attitude, emotional and behavioral reactions also a perception about happening around him (Angelica, 2015).

Culture is a national identity that should be maintained, respected, and preserved for the existence of Indonesian culture and future generation legacy. Culture in Indonesia is called national culture. Furthermore, Indonesia has various popular cultures in the world, such as wayang kulit, batik art, dances, a traditional ceremony for a wedding ceremony, give birth, and other various customs. Indonesia has various types of regional art like music, song, dance, and performing arts. The variety of art and culture become Indonesian values and characteristics. Cultural values characterize social groups, such as nations, business organizations, education systems, and religions. At the individual level, personal values are cognitive representation purposes to motivate an individual behavior (Schwartz, 2008).

Indonesian cultural diversity became an Indonesian citizen pride and country in the world. Thus, it is a big task for the youth and Indonesian citizens to participate in caring, safeguarding, maintaining, and preserving local culture so it is not lost or recognized by other countries. By preserving local culture, Indonesian people can protect the nation's culture from foreign cultural impact. A culture describes nation identity, this cultural orientation also shows dependence on belief expansion of people nation (Schwartz, 2014).

There are many caused local culture to be forgotten by the current generation, one of foreign culture in midst of local culture. In facts, many young Indonesians prefer foreign cultures because it is unique more and interesting. Many local cultures are faded because of no successor generation. It is the young generation's responsibility to raise self and community awareness of the importance of caring, maintaining, and preserving Indonesian local culture also increasing nationalism sense.

\subsection{Art as a Cultural Communication Medium}

Art is originated from the root word of art. Art means the skill of making the quality of an artwork, created with extraordinary skills, such as dance, painting, carving. Art refers to beauty (aesthetics) value originated from human desire expression for beauty. (Kurniawan:2012) says art means an expression of beauty from the human soul. Still, art is communication media for the community to the environment or other community groups. (Soemaryono:2011) said art as an element of culture consists of art branches, like a dance. The dance form has related to feelings, like exhilarating, touching, or maybe disappointing. Exhilarating and touching because dance can touch one's feelings to be happy after enjoying the show with satisfaction. Dance in a particular culture or society is the realization or embodiment of human-environment expression (Desfiarni:2004).

In the cultural communication process, the media is traversed by messages or symbols. Two types of social scientists agree on channels, it sensory channels, that transmit messages channels, so five human senses could catch by light, hand sounds, nose, and tongue. (Ridwan:2016) Communication media are channels used to produce, reproduce, distribute, and information deliver. In this modern era, media and communication are unseparated. Communication media has a big role in community lives. Without the media, people are difficult to do a communication process. 
Communication media is also very needed in social life because its function helps for the better communication process. The communication media easily deliver communication to be better, effective, and efficiently more. In addition by using communication media, accelerate the abstract (concrete) messages. Moreover, communication media also has a motivational function that makes communicators and communicants more enthusiastic in do the communication process. Communication culture and media, usually refer to three things: mutual trust and knowledge system, commonly called a system of meanings and symbols; values set, beliefs, and practices; it is shared as communication (Klinenberg, 2013).

Indonesian art is an origin from his grow places and different environments one to another. Art develops among the community that is rooted and sourced from his community traditions environment. Art is made by the Indonesian tribe's diverse creativity, so it's regionality. Cultural events are the main basis for the implementation of performing arts. Performing arts, especially dance with sounds are the bearers of magical powers that are expected to be present. Performing arts has several functions, firstly, art has ceremonial purposes, the completion of the ceremony is a manifestation to express beauty. Second, art functions as an expression media. Art is an expression media for artists in the community and becomes their daily life. Besides being a creator, he can also participate in the development of the arts. So, art can be part of routine activity and entertainment too.

The next function is an art as an entertainment medium. Art's main function as a ceremony medium has shifted, it is an entertainment medium that contains moral values and develops in traditional society. Except as an art entertainment medium, it is also an education medium function. Art as an educational medium is to find the noble values contained in the show symbols. Morality and messages of educational content are easily accepted by traditional society, it happens because of the familiarity of the story in the audience's audio.

\section{Methodology}

In this research, the approach uses a qualitative descriptive approach. This approach has chosen to obtain objective and in-depth qualitative data forward to the research can be presented descriptively so the research results findings are presented in sequence, detail, and depth. Qualitative descriptive is used by researchers to describe or construct in-depth interviews with research subjects.

The research subjects were the sinoman hadrah performers and some Sei Teras village, a subdistrict of Kapuas Kuala community who knew more about the art of sinoman hadrah. The object is what thing will be investigated in this research. Some problems are needed to understand by researchers to determine and arrange research objects in good research methods, it related to what an object of qualitative research, and the worth things of being an object of research. The research object is communication science related to Cultural Communication and the role of sinoman hadrah art media.

\section{Result and Discussion}

Communication success is determined by the ability of the communicant to give meaning to the message received, if the meaning intended by the communicator and the communicant is the same, then communication is successful, in achieving the same meaning. Besides the background of personal experience, norms, customs, beliefs also affect the "field experience" to an object and finally affect the perception of an object. Culture serves to teach the communicating procedure, verbally and non-verbally, communication becomes a socialization tool for cultural values to the community, through verbal and non-verbal communication transmitting cultural values, social norms, and customs from one generation to generation, from one group to another group. Indonesia has a rich culture that makes the communication science treasures more colorful and becomes a united medium to harmonious life, valuable and meaningful for all groups with profiles and uniqueness (Fam \& Gzaley, 2020; Schewe \& Noble, 2000) said every group has a unique profile (eg characteristics, values, attitudes, and preferences) because group member has experienced different external events.

Sinoman hadrah is a Banjarese cultural art contains to philosophical and Islamic cultural values, sinoman hadrah usually show in various religious events, circumcision, bridal processions, and welcoming honorary guest. Sinoman hadrah are origin from sinoman and hadrah words. Sinoman means a male qasidah group to welcome guests or a placeman, while hadrah means presenting by techniques. Sinoman hadrah is an art that gets colorful of Islam and an art form grows and develops. This art consists of five or six singers who play tambourine as well, then play jellyfish umbrella with rudat dancers, totaling 20 to 30 people. Sinoman hadrah is usually shown at welcoming honorary guest events. The honorary guest is usually a government who comes to the village for a gathering or to inaugurate something. Sinoman hadrah also used to welcome Islamic / national days and wedding ceremonies.

At the wedding ceremony, sinoman hadrah is shown when the groom is brought to the bride's residence to be juxtaposed (procession), approximately $1 \mathrm{~km}$ of the journey before arriving at the bride's house, sinoman hadrah is immediately played with songs (poems) by the bearers or poetry readers (Khair, 2003).

The role and involvement of the community are highly expected in the implementation of sinoman hadrah art. Involvement is defined as people's daily involvement with various media. It affects self and group awareness 
of the community to the social change context and globalization also technological advances (Takahashi, 2010). From the direct involvement made the communication process in moral messages deliver with the sinoman hadrah art media can be achieved as expected.

A formed communication from the Sinoman Hadrah art is very deep and full of meaning, cultural element inherent to Banjar tribe lives, and reflection is well known as peaceful and harmonious. Sinoman hadrah become a communication medium and art contained to Islamic values essentially in life principles set, teachings about how humans should live in the world and respect to each other. In the Sinoman Hadrah performance, there are three main values to be conveyed: morals, harmony, and ukhuwah Islamiah.

(Adisusilo, 2013: 54) quoted a Sastrapratedja's statement, the first value is moral, it is a value system about how a person should live well as a human being. Morality contained to the rules of social life habits, such as traditions, advice, regulations, advice, orders, prohibitions, and others. Based on observations at the research time, in the implementation of the process of sinoman culture, there are moral values. For example, when the Sinoman culture members are younger speak or communicated used polite sentences to the older, it indirectly shows the Sinoman culture has good moral values fit to Adisusilo's opinion that morals are a value system about how one should live well as human being.

The second value is harmony, the harmony of religious life contained three important elements: first, the willingness to accept different beliefs with other people or groups. Second, the willingness to allow others to practice their beliefs teachings. And third, the ability to accept differences then enjoy the atmosphere of solemnity other people feel when they practice their religious teachings. In sinoman culture, there's a harmony value between fellow people or different aqidah people, based on observations when sinoman culture are going good relations were established between fellow people and different aqidah people accepted well what Muslim people commonly.

The third value is ukhuwah islamiah. Ukhuwah is originally from Arabic language whose root word is akh means frater meanwhile ukhuwah islamiyah is the power of faith and spirituality Allah to His servants who believe and are pious, which grow love feelings, fraternity, glory, and mutual trust people in one faith. With ukhuwah there will be a mutual help attitude, understanding, and not oppressing others' wealth or honor, which arise because of Allah. Based on observations when the sinoman culture was in progress, there were good relations between fellow Muslims or Muslim communities who carried out the sinoman culture or participated in this culture, such as mutual respect for one another and mutual help.

In sinoman hadrah performance, there are several kinds of used tools, like tambourines (flying), baboons, ketipung, tambourines (chimes), flags and decorated large umbrellas. The use of tools in the senoman hadrah art is one of media management to invite community participation at the art events series because media management invites to participate in generating cultural content to interact and collaborate between communities (Fuchs, 2017).

Welcoming the honorary guest who came to Sei Teras village began when the guest out from the car or boat then immediately sholawat recited at three times, continue with the draping of flowers. After draping the flower, the sinoman hadrah music started while the guests were under a rotating large ornamental umbrella until the guests sat on a chair

There are several goals to be achieved in the sinoman hadrah performance as a communication medium of Islamic culture and art according to (Khair, 2003):

1. Build young generation potential to Islamic society art

2. Develop the regional culture and arts Islamic

3. Increasing unity and integrity among the younger generation

4. A communication medium to spread Islamic teaching

5. Increase self-confidence

6. Restrain the foreign cultures that contradict Islamic values

7. Build tolerance and respect mutual.

In the sinoman hadrah culture process, there are Islamic values, one of which is harmony value. The harmony value in the sinoman hadrah cultural process cause of the cultural performances by the community, by doing this culture made a good communication and an association medium to the community in one village to others. (Interview with Yusuf Anwari: 10-02- 2021).

The sinoman hadrah culture is an inherited Islamic culture, the Islamic values contained to Ukhuwah Islamiyah value it means Islamic fraternity. The sinoman hadrah cultural process in a marriage made a love, fraternity, and fellow harmonious. (Interview with H. Baktiannoor: 11-02-2021).

In the process, we will follow all sinoman hadrah activities or implementation, especially welcoming the honorary guest, from the beginning to the end. Moreover when gathering the sinoman hadrah members, praying, forming a line, walking from the event venue or the house where the honorary guest visited, sholawat and poetry side by drums (tarbang) and sinoman hadrah cultural dances. From these activities, Islamic values education, tolerance, the communication medium is harmony, harmony among communities who participate in the 
procession. (Interview with Idris: 11-02-2021).

The Sinoman Hadrah culture use equipment or movement a lot but the Islamic value is clothing, Sinoman participants are required to use closed clothing to cover the genitals while dance and sing sholawat in an enthusiastic community about the culture. Meanwhile, a piece of equipment is only a support thing to beautify sounds or dances such as drums (tarbang) and flags. this thing has become uniqueness medium for Sei Teras people in preserving Islamic art and culture. (Interview with Baihaki: 12-02-2021).

Sinoman hadrah is one strong Islamic value of Banjar tribe cultural arts and suited with Indonesian people who Muslim are dominant, therefore it needs to develop maximized. There are many problems in Sinoman hadrah development, the main factor was the lack of teenage interest to pursue this art because they are more interested in modern art that was vulgarly packaged and could damage morals. Teenagers are easily influenced by west culture considered modern. This situation is supported by sophisticated communication media at this time, so something is easily obtained. All outside information can no filtered longer by the government it is affected by positive and negative information that can enter Indonesia. The implementation of senoman hadrah art can create mutual respect in Sei Teras village in Kapuas Kuala community especially, if the arts can be carried out properly and welcomed by the enthusiastic community to participating in various senoman hadrah events, so "thank you" are interactions communication result and describe the happiness of the performers. They are grateful for the behavior including everyone who wanted an entertainment experience type (Jenkins, 2006: 2).

Positive efforts for fostering and developing the younger generation need positive efforts and activities, as a famous community of various culture and arts, the art activities contain to religious values are very appropriate to preserved and cultivated one of is Sinoman hadrah art. Sinoman hadrah is Islamic art that can be used as art media, communication media, and da'wah media by advice poems, praises to the Prophet invited people to live in mutual respect, morality, harmony, and peace. Therefore, the sinoman hadrah art must be socialized to all young generations, Sei Teras village in Kapuas Kuala people especially.

To maintain the community preservation and enthusiasm to do senoman hadrah art performance as communication medium must be innovated with modern art like a fandom artwork, but not change the Islamic originality because fandom characterized is a strong bond social among the members from their constant interaction and exchange information in community (Sullivan, 2012).

\section{Conclusion}

Society characteristics inherent to an art show the original place. Art is closely related to the communication study because a cultural life also must understand a cultural communication concept. Culture is a national identity that must be maintained, respected, and preserved for culture to exist and heritage for future generations. Culture has an integrative function to provides basic and orientation community members to create enthusiasm, safety, belonging, taste as a community. In this modern era, media and communication can no longer be separated. Communication media plays a big role in people's lives. Without it, people would hardly do a communication process. Art's main function as a ceremony medium has shifted, it is an entertainment medium contained to moral values and develops in traditional society, so the media and art are more interesting and unique in the community for message delivery or culture communication.

Cultural communication is based on hadrah senoman doing through on two communication forms, verbal communication through poetry and nonverbal communication through clothing, movement, and equipment. A message from the Senoman Hadrah art was many contained to cultural elements as a unique communication medium in messages deliver to the people as cultural messages, morals, and mutual respect. For the Banjar tribe, cultural communication through the Senoman Hadarah performance becomes a symbol of media and art for welcoming honorary guests at Sei Teras village in Kapuas Kuala also a hereditary culture to be preserved for future generations that culture is part of the tribe honor and identity.

Sinoman hadrah is Islamic art that can be used as communication media of culture and da'wah by an advice poem, praises to the Prophet invited people to do good and show Banjar tribe identity who major in Muslim and known as the province of arising a great scholar. Therefore, the sinoman hadrah art needs to socialize in young generations, young Muslim especially. Considering the senoman hadrah are suitable with Indonesian people who Muslim are dominant so need to develop maximized. Even though there are obstacles, these obstacles can be solved one day, such as love instilling for traditional arts to the young generation. Moreover, the Sinoman Hadrah art can be a fandom or work which follows the modern world development, so the young generation didn't bored when watching the performance without changed the authenticity especially in Islamic values, culture, and respect one to other. In addition sinoman hadrah doesn't seem to consistently think continuously and look more attractive in cultural uniqueness inherent to the Banjar tribe as an identity to respect an honorary guest because it is Indonesian ethics to respects any nation.

\section{References}

Adisusilo, S. (2013). Pembelajaran nilai karakter. Jakarta: PT. Raja Grapindo. 
Angelica, N. (2015). Culture and gender role differences.Cross-Culture Management Journal, Volume XVII, $1(7), 31-35$

Anwari, Yusuf. Wawancara Pribadi, 10 Februari 2021. Sei Teras Kapuas Kuala.

Bakhtiannor. Wawancara Pribadi, 11 Februari 2021. Sei Teras Kapuas Kuala

Baihaki. Wawancara Pribadi, 12 Februari 2021. Sei Teras Kapuas Kuala.

Bourdieu, P. \& Wacquant, L. (1992). An Invitation of Reflecive Sociology. Cambridge: Polity Press.

Burgess, J. \& Green, J. (2009). Youtube Online Video and Participatory Culture (First Edition). Cambridge: Polity Press.

Desfirni. (2004). Teori Lukah Gilo. Yogyakarta: Kalika.

Duffett, M. (2013). Understanding fandom: An introduction to the study of media fan culture. London, UK: Bloomsbury Academic.

Fuchs, C. (2017). Social media: A critical introduction. London, UK: SAGE Publications.

Gorden, William. (1978), Communication:Personal and Public. Sherman Oaks: CA Alfred

Idris. Wawancara Pribadi, 12 Februari 2021. Sei Teras Kapuas Kuala.

Ito, M. (2010). The rewards of non-commercial production: Distinctions and status in the anime music video scene. First Monday, 15(5).

Jenkins, H. (2006). Convergence culture: Where old and new media collide. New York: NYU Press.

Kapferer, J., N., \& Michaut-Denizeau, A. (2020). Are millennials more sensitive to sustainable luxury? A crossgenerational international comparison of sustainability consciousness when buying luxury. Journal of Brand Management, 27(1), 35-47. doi:10.1057/s41262-019-00165-7

Khair, A. (2003). Sinoman hadrah eni Islam yang perlu mendapat perhatian. Himmah, 4(2), 45-54.

Klinenberg, E. (2013). Culture, Media and Communication. Journal of Culture, Media and Communication. 118139.

Kurniawan, Benny. (2012). Ilmu Budaya Dasar. Tanggerang Selatan: Jelajah Nusa.

Ridwan, A. (2016). Komunikasi antar budaya mengubah persepsi dan sikap dalam meningkatkan kehidupan manusia. Bandung: Pustaka Setia.

Sagiv, L., \& Schwartz. S. H. (2000). A new look at national culture: Illustrative applications to role stress and managerial behavior. In N. N. Ashkanasy, C. Wilderom, \& M. F. Peterson (Eds.). The handbook of organizational culture and climate (pp. 417-436). Newbury Park, CA: Sage.

Sagiv, L., \& Schwartz. S. H. (2007). Cultural values in organizations: Insights for Europe. European Journal of International Management, 1, 176-190.

Schewe, C. D., \& Noble, S. M. (2000). Market segmentation by cohorts: The value and validity of cohorts in America and abroad. Journal of Marketing Management, 16, 129-142.

Schwartz, S. H. (2008). Cultural value orientations: Nature \& implications of national differences. Moscow: State University Higher School of Economics Press.

Schwartz, S. H. (2014). National culture as value orientations: Consequences of value differences and cultural distance. In V. A. Ginsburgh, \& D. Throsby (Eds.), Handbook of the Economics of Art and Culture (Vol. 2) (pp. 547-586). Amsterdam, Netherlands: Elsevier.

Sharipudin, M. S., Fam. K., Gazley. (2020). Media self-congruity among the generational cohorts of Boomers and Gen Y in Malasysia. SEARCH Journal of Media and Communication Research, 12(3), 87-102

Spano, C. (2016). Audience engagement with multi-level fictional universes: The case of Game of Thrones and its Italian fans. Participations: Journal of Audience \& Reception Studies, 13(1), 625-655.

Sullivan, J. L. (2012). Media fandom and audience subcultures. In J. L. Sullivan (Ed.), Media Audiences (pp.189-212). London, UK: SAGE Publications.

Sumaryono. (2011). Antropologi tari dalam perspektif Indonesia. Yogyakarta: ISI Yogyakarta.

Swidler, Ann.(1986). Culture in Action: Symbols and Strategies. American Sociological Review 51(2), 273-286

Takahashi, T. (2010). Audience activity, everyday life, and complexity. In T. Takahashi (Ed.), Audience studies: A Japanese perspective (pp. 11-37). NY, London: Routledge.

Trice, H. M., \& Beyer, J. M. (1993). The cultures of work organizations. Englewood Cliffs, NJ: Prentice-Hall. Williams, R. M. (1970). American society: A sociological interpretation (3rd ed.). New York: Knopf.

Muzahid Akbar Hayat is a lecturer at the Postgraduate Faculty of Communication Sciences, Islamic University of Kalimantan. He holds an M.I.Kom degree from London School University Jakarta and a PhD from Pandjajaran University, Bandung. Set himself especially as communications study part and become one of youngest lecturers in Indonesia who already has a Ministry Decree as Lector or Assistant Professor.

Rico is a student at the Postgraduate Faculty of Communication Sciences, Islamic University of Borneo. Currently studying semester 4 . 